Werner Hermann, an economist at the Swiss National Bank, was a visiting scholar at the Federal Reserve Bank of St. Louis. G. J. Santoni is a protessor of economics at Ball State University. Santoni's research was supported by the George A. and Frances Ball Foundation. Scott Leitz provided research assistance.

\title{
The Cost Of Restricting Cor- porate Takeovers: A Lesson From Switzerland
}

M ANY PEOPLE in management, labor, banking and Congress are alarmed about the recent increase in corporate takeovers. These people believe that the risk of a takeover is detrimental to the efficient management of corporations and not in the long-run interests of the owners (see shaded insert on following pagel. As a result, they have advanced various proposals to restrict corporate takeovers. ${ }^{1}$

Others have a different view of takeovers, believing that restrictions of takeover activity will be harmful to shareholders' wealth. They argue that takeover activity is a simple manifestation of competition in the market for corporate control. ${ }^{2}$ Furthermore, by inducing corporate management to weigh the effect of its decisions on the present value of the corporation land, thus, share prices), this competition provides strong protection for the interests of all shareholders including those of "non-controlling" shareholders. ${ }^{3}$ According to this view, the threat of takeovers is important to maintaining an efficient corporate sector. ${ }^{4}$

A recent change in Swiss commercial practice provides important new evidence about the consequences of restricting corporate takeovers. The Swiss Commercial Code in the past has allowed corporations to build effective barriers against takeovers. Many Swiss firms have taken advantage of this legal provision to protect themselves against foreign raiders. On November 17, 1988, Nestle (by far the largest Swiss corporation) announced that it would allow foreign investors to buy a type of share that only Swiss citizens could hold until then. Since then, a foreign takeover of Nestle has been possible, at least in principle.

Nestle"s announcement and the events sur. rounding it have important implications for U.S. proposals to restrict takeovers. This paper examines data on the share prices of Nestle and
These include restricting voting rights to those who have owned the stock for a minimum of one year, disallowing interest deductions from taxable income on certain types of bonds used to finance takeovers and a "sliding scale" capital gains tax rate that is lower the longer an asset is held before sale. In addition, there are at least five Senate and House panels that are planning to hold hearings on leveraged buyouts and other types of debt-financed takeovers. See Hersthey (1988), Anders and Swartz (1988), Norris (1988) and Passell (1988).
2See Manne (1965), Manne and Ribstein (1988) and Jensen and Ruback (1983).

3See Manne (1965), p. 113.

4 See Manne and Aibstein (1988), p. 29. Some have singled out an anti-takeover bill approved by the House Ways and Means Committee on October 15, 1987, as an important contributing factor to the stock markel crash on October 19, 1987. See Ricks (1989). 


\section{Some Views On Hostile Takeovers}

Vout e going to have a thinch of lighly. leveraged companies that atent going 10 be able to weanter a linancial storm.

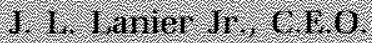

West Poni-penperell inc

If if nade sense to pui the company. together for economis strengli in the hegin: hing then in comainly nakes no sense to breal it apart:

John Ie torean.

former cteneral Motors executive

Thave io wonder if theres some kind of structural mbalanee in the linancial markets if the sanu package of assets hroken into piees are worlh twice what the market puls on them when all logether:

Johin R. Hall, C.E.O.

Ashlatid vil line.

People are questroming a whole series of this kind of activity particutarly in the light of al the foreign nvestment in this country.
They re questioning the theory that many people are so chamored with the whole me now: bighit generation of 28 veor-atd nillionames on Wall street who havent con tributed to the countrys econony And a hell of a lor of people resent hat:

Phillip I. Bion e t $6 \mathrm{~d}$

bel Webl comp.

"Itow could it possibly help the company to be that muely in debt? How does it help the employees? How can the company progress. how ean they do tesearch and development" Cinu Jala C.1.0.

Dixon ticonder gga Co.

Where is no question that the Committee on Ways and Means will be lobking at leveraged buy ours and nergers and acquisitions and do somelling almut it: Dan Rosicnkowsk, Ghaiman Commitee on Ways and Means. other Swiss firms around the November 1988 announcement date to analyze the effect of this sudden change in policy on shareholder wealth. If the data indicate that investors in Swiss stock generally benefited when restrictions against foreign takeovers were relaxed, current U.S. proposals to limit takeovers are likely to be counterproductive in protecting shareholder wealth.

\section{STOCK PRICE PUNDAMENTALS}

Since stock prices represent the market value of a firm, they play a significant role in the analysis of this paper. Therefore, it is important to understand how they are determined.

People value common stock for its expected return. Since investors may choose among broad categories of stock, the expected return on any particular stock must be equal to the expected return on other stocks of similar risk. For example, if a particular stock is expected to yield a relatively low return, investors will shun it, causing its price to fall and its expected return to rise until its yield is equal to that of similar stocks. The reverse holds for any stock with an expected return higher than other stocks of similar risk. An equilibrium exists when expected returns are equal across stocks with identical risk characteristics. The equilibrium return is called the required discount rate.

Equation 1 calculates the expected rate of return (r) from holding a share for one year assuming dividends (d) are paid at year-end: ${ }^{5}$

(1) $E_{t}\left(r_{t, t+1}\right)=\left(E_{t} P_{t+1}+E_{t} d_{t+1}-P_{t}\right) / P_{t}$.

Equation 1 says that the expected return at time $t$ of holding a share of stock from $t$ to $t+1$ is equal to the expected price of the stock at the end of the period $\left(\mathrm{E}_{t} \mathrm{P}_{\mathrm{t}+1}\right)$, plus the expected dividend $\left(E_{t} d_{t+1}\right)$ less the current price of the stock $\left(\mathrm{P}_{t}\right)$, all divided by the current price.

Equation 2 solves equation 1 for the current price by noting that the expected return equals the required discount rate (i) in equilibrium: 
(2) $\mathrm{P}_{\mathrm{t}}=\left(\mathrm{E}_{\mathrm{t}} \mathrm{P}_{\mathrm{t}+\mathrm{t}}+\mathrm{E}_{\mathrm{t}} \mathrm{d}_{\mathrm{t}+1}\right) /\left(1+\mathrm{i}_{\mathrm{t}}\right)$.

Equation 2 indicates that investors must forecast the price of the stock next period. What are the fundamentals of this price? In principle, the future price depends on the earnings of the company, dividend payments, and the required discount rate that investors expect to prevail over the life of the firm. If dividends are expected to grow at a constant annual rate (g) and the discount rate is constant, the calculation shown in equation 2 can be simplified as in equation $3:^{6}$

(3) $P_{t}=d_{t}(1+g) /(i-g)$.

Equation 3 gives a relatively simple solution for the current stock price. For example, suppose the current dividend is $\$ .98$, the required discount rate is 12 percent and the expected growth rate in dividends is 2 percent. Equation 3 indicates that a share of stock in this firm will trade at a price around $\$ 10[=\$ .98(1.02) /(.12-$ $.02)]$.

\section{TAKEOVERS AND THE FUNDAMENTALS}

Equation 3 is a useful summary of the fundamentals that determine stock prices. It indicates that stock prices change when one or more of the fundamentals change. Furthermore, it is useful in contrasting the views of the proponents and critics of takeovers.

Critics of takeovers believe that competition for the control of firms adversely affects the fundamentals. For example, they argue that takeovers increase tension between management, labor and government to the detriment of future earnings and dividends; or that increases in the target's debt-to-equity ratio that accompany many takeovers increases the risk (and the discount ratel associated with the firm's expected eaming stream; or that takeover threats force management to concentrate too heavily on projects that promise increased earnings in the near term at the expense of long-term research and development.

Others argue that the threat of takeovers improves the fundamentals on net because they

Brealey (1983), p. 69. The curent price is defined by equation 3 ony if the expecied growth rate of dividends is less than the discount rate.

7See Manne (1965), Manne and Ribstein (1988) and

Alchian (1977), pp. 227-58. induce management to use the firm's resources in ways that generate higher returns for the owners. They point out that the interests of management and shareholders can diverge and that it is costly for shareholders to monitor management's decisions. In the absence of strong competition from alternative management teams, the firm's managers, acting in their own interests, can capture a portion of the stream of earnings that would otherwise accrue to the shareholders. This may come in the form of high management salaries, large expense accounts, plush offices, lengthy vacations and other forms of shirking. Shirking affects the distribution of earnings between the firm's management and its owners. Furthermore, it may lower the stream of earnings generated by the firm. The cost associated with this type of behavior, called "agency cost," lowers the expected stream of dividends that accrue to shareholders and is reflected in lower share prices. $^{7}$

The reduction in share price due to agency costs is a measure of the capital gain that could be obtained from a successful raid. According to this argument, competition among alternative management teams in the market for corporate control assures that agency costs are kept to a minimum, resulting in higher share prices for firm owners. ${ }^{s}$ Thus, this theory suggests that takeover activity raises stock prices while the one mentioned earlier implies the opposite.

What evidence is there to support either view? Data on U.S. takeovers suggests that they raise stock prices. ${ }^{9}$ The recent changes in the Swiss stock market should make Swiss data particularly useful in adding to this body of evidence.

\section{SWISS STOCK MARKET MNSTWUU- TMONAL DETAILS}

\section{Registered, Beaner and Non-woting Shares}

Swiss law allows corporations to issue several types of shares called bearer, registered and non-voting shares. Bearer shares are the equivalent of the typical common share issued by

8See Manne (1965), p. 113, and Ruback (1988).

9See Jensen and Ruback (1983). 
U.S. corporations. Ownership of a bearer share entitles the holder to the dividends and one vote at shareholder meetings. They can be transferred without restriction.

Registered shares differ from bearer shares in several important respects. For example, the purchase of a registered share entitles the buyer to dividends but does not grant the new owner the automatic right to vote at shareholder meetings. To obtain voting rights, the new owner must apply to be "registered" in the firm's book of shareholders. Until the new owner is registered, the voting right remains with the previous (and still registered) owner. Registration of the new owner, however, is not automatic. The corporate charter can summarily exclude certain investors from registration. ${ }^{10}$ Furthermore, Swiss stockbrokers have declared publicly that they will refuse to exercise buy orders from clients that are unlikely to qualify for registration. ${ }^{11}$ While registration is often restricted to Swiss citizens or institutions and, thus, can effectively prevent foreign takeovers of Swiss firms, this tool has been used to block Swiss raiders as well. ${ }^{2}$

A glance at the stock market page of a Swiss newspaper reveals that about a third of the Swiss corporations issue registered shares. Because these firms typically issue more registered shares than bearer shares, registered owners hold the controlling interest in the companies that issue both. ${ }^{13}$ Coupled with the provisions regarding registration, this gives these Swiss firms ironclad protection against hostile takeovers.

Besides registered and bearer shares, large companies issue securities that pay dividends but have no voting rights associated with them. Holders of these non-voting shares (participation certificates) have virtually the same rights as voting shareholders, apart from the right to vote.

\section{Different Pat Values}

Dividend payments and the share of the firm's liquidation value that accrue to Swiss stockholders are proportional to the par value of the

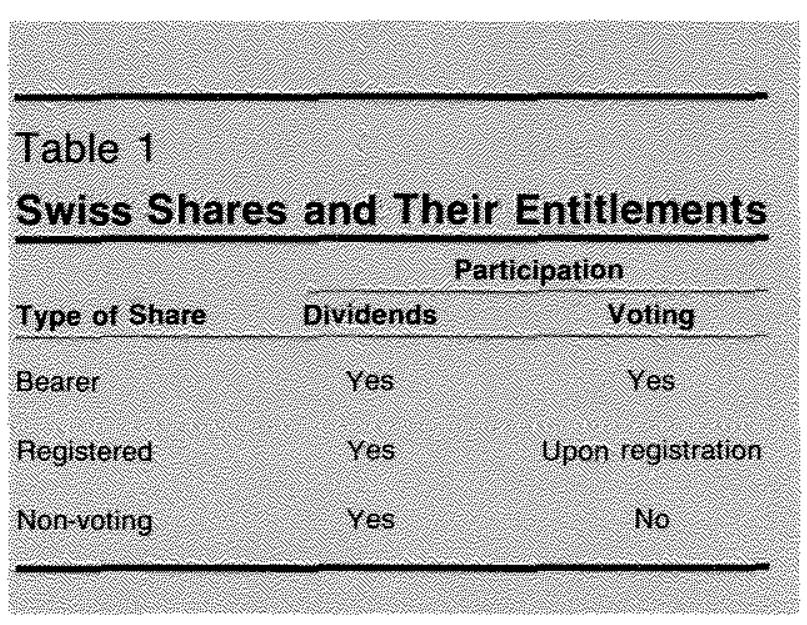

shares they hold. Both registered and bearer shares carry one vote. Swiss firms, however, are allowed to issue registered shares with lower par values than bearer shares. For example, let $R$ be a registered share with a par value of $\$ 50$ while $B$ is a bearer share with a par value of $\$ 100$. Both shares carry one vote but the expected stream of dividends generated by the registered share is one-half that of the bearer share. Other things the same, the registered share will trade at about one-half the price of the bearer share. Table 1 summarizes the participation rights of the different types of shares.

\section{NGSTING UP TO SHARE HOLDERS}

To the surprise of many market participants, the common Swiss practice of discriminating against foreign investors was suddenly changed on November 17, 1988. Nestlé, the Swiss multinational foods group, decided to register shares of foreign investors. Nestle had been repeatedly criticized for attempting to take over firms in countries outside Switzerland while being protected from foreign acquisition. In a release that accompanied the announcement, Nestle's finance director explained that "there was a contradiction between being multinational in our behavior and national in our share control," ${ }^{4}$

bidder for La Suisse withdrew his offer after the La Suisse board announced that it would refuse to register the bidder's shares.

13See "Shareholders, Who Are They?" (1989). For the number of shares issued of each type, see Swiss Bank Corporation, (1987).

\footnotetext{
to See Horner (1988) and Foreman (1988). In the 1930s, this festriction was used to prevent takeovers of Swiss firms by firms in Nazi Germany. See "Shareholders, Who Are They?" (1989).

1:See Horner (1988), pp. 70-71, and Foreman (1988).

12See Dullforce (August 9,1988 ) and Wicks (August 2, 1988), who report on the takeover battle for La Suisse, a Swiss insurance company. In that case, the highest Swiss
} 
Because of Nestle's relative size, its decision was viewed as extremely important by market participants. ${ }^{15}$ Since then, several other Swiss firms have made similar announcements ${ }^{16}$ Furthermore, the Swiss parliament is currently considering revisions to the commercial code that would make Swiss firms more accessible to outsiders. In part, such revisions have been prompted by Swiss shareholders who claim that they are adversely affected by anti-takeover rules. On the other hand, some Swiss citizens believe that hostile takeovers could harm Swiss companies and that management should be protected from raiders. Although the outcome of this debate is uncertain, the decision by Nestle and other Swiss tirms to liberalize shareholder registration marks a significant step in changing Swiss commercial practices regarding corporate takeovers.

The theory of the market for corporate control suggests that impediments to takeovers are costly, which means that they reduce shareholder wealth. According to this theory, one consequence of reducing impediments to takeovers is that the capitalized value of the firm increases. To test this, data on Nestle's share prices before and after November 1988 are examined. Since Nestle's decision is viewed as having important consequences on the entire Swiss stock market, share price data on 44 other firms traded on the Zurich exchange are examined as well. ${ }^{17}$

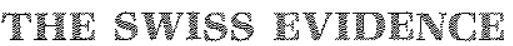

To determine the effect of the loosening of voting restrictions on corporate shares in Switzerland, daily closing prices are analyzed at three points in time: the last trading days in December 1985, July 1988 and December 1988. The July 1988 date leads Nestle's announcement by about three months to minimize the possibili- ty that advance information about the forthcom. ing announcement might affect prices. The December 1988 date is the month immediately following the announcement month. The reason for choosing the December 1985 date is discussed below. The sample consists of nine firms that issue only bearer and non-voting shares, 21 firms that issue all three types of shares and 15 that issue only registered and bearer shares. A list of the firms appears in the appendix. The data are adjusted for differences in par values between different share types of the same company.

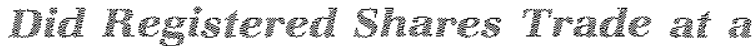

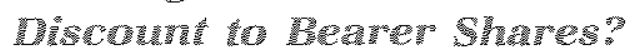

The first question examined is whether regis tered shares typically traded at a discount to bearer and non-voting shares of the same firm before November 1988. ${ }^{18}$ Table 2 shows the ratios of the prices of registered to bearer and registered to non-voting shares for the same firm at three points in time: December 1985, July 1988 and December 1988.

The 36 firms in this sample differ in several respects. Some issue non-voting shares; others do not. In addition, some of the firms in the sample issue registered and bearer shares with the same par values while others issue these shares with different par values. Table 2 examines data on the price ratios while controlling for these differences.

Panel A of table 2 shows the mean of the ratio of registered to bearer share prices for the 21 companies that issue all three types of shares. The data are prices for the close of the last trading day of the month. The null hypothesis that the mean of the price ratios is one is rejected at a 5 percent significance level for the two dates before November 1988 but not for the December 1988 prices. The ratios for the December 1985 and July 1988 dates are indis. tinguishable in a statistical sense, suggesting

\footnotetext{
14A practical motivation for the decision was suggested by William Dullorce who commented that 'Nestle's access to capital markets was restricted by the differentiation bet* ween registered and bearer shares." See Dullforce (November 18, 1988).

15The value of Nestle shares account for about 10 percent of the total Swiss stock market. See "Shareholders, Who Are They?' (1989), p. 69.

16The most recent firm to make a similar announcement is Jacobs Suchard, a coffee and chocolate concern. See Wicks (June 22, 1988).
}
77The Zurich stock exchange is the largest in Switzerland. More than 400 Swiss and foreign companies are listed on this exchange along with a much larger number of bonds.
18Some have argued that tax considerations and differential transaction costs imply that registered shares will sell at a discount to bearer shares. Since these factors did not change during the period analyzed, however, they cannot explain significant changes in relative share prices associated with Nestle's decision to allow foreigners to purchase its registered shares.




\section{Table 2}

\section{Price of Registered Relative to Bearer} Shares For Selected Months

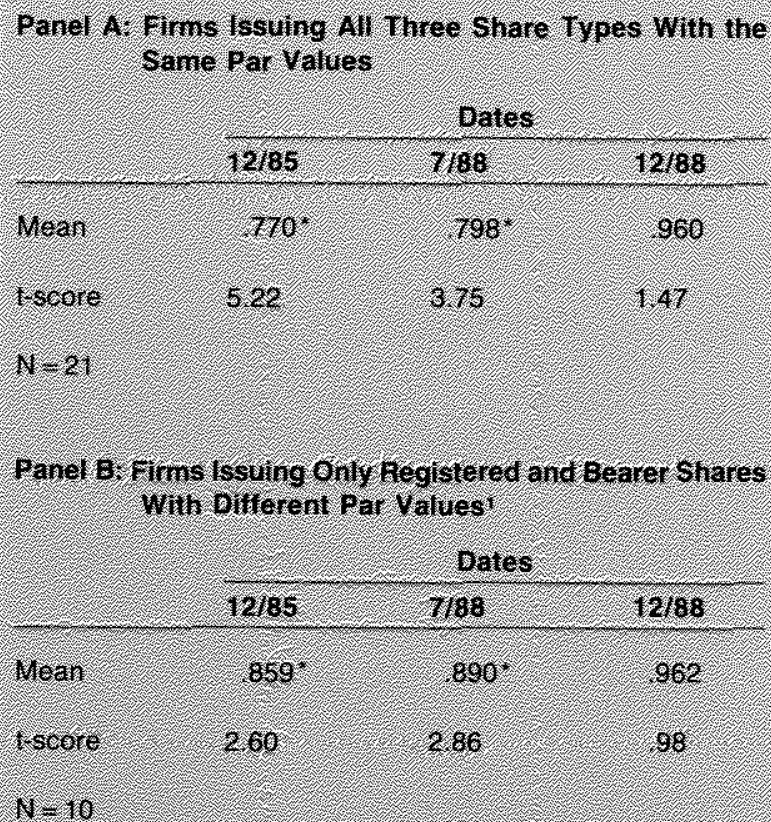

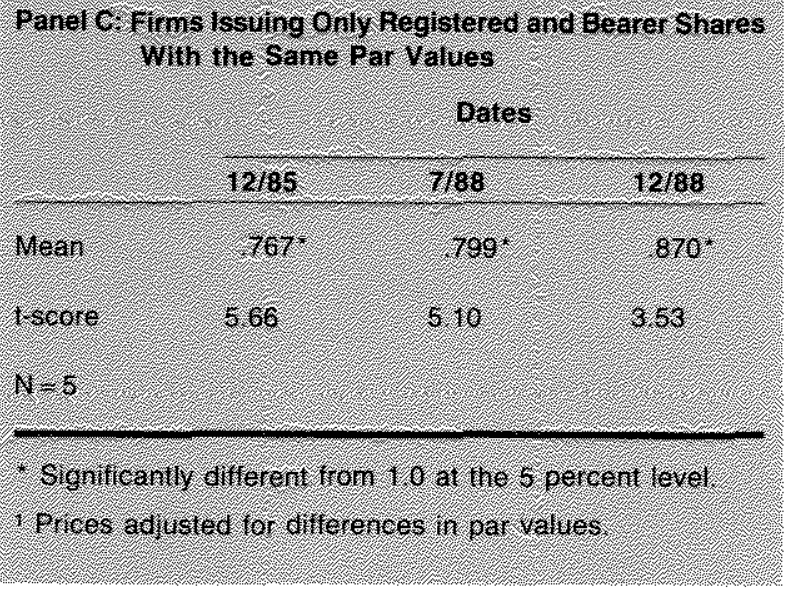

that the discount on registered shares prevailed long before Nestle's announcement. ${ }^{19}$ This discount vanished, however, by December 1988.

The panel $B$ data differs from the panel $A$ data in two respects. The price ratios in panel $B$ cover firms that issue only registered and bearer shares (no non-voting shares). Furthermore, the par values of each firm's registered shares are lower than the par values of the bearer shares for the firms in this panel. Since the stockholders of Swiss firms share dividends in proportion to the par values of the shares they hold, registered shares with lower par values than bearer shares should sell at a discount to bearer shares regardless of ownership restrictions on registered shares. To control for this "par value" effect, the registered share prices of the panel $B$ firms are adjusted for differences in the par values.

The results shown in panel $B$ are similar to the panel $A$ results. The mean of the ratios of registered to bearer share prices is significantly less than one before November 1988 but is statistically indistinguishable from one for the December 1988 data.

The data in panel $\mathrm{C}$ cover firms issuing only registered and bearer shares with the same par values. The results shown are similar to the panel $A$ and $B$ results for data before November 1988. The result for the December 1988 data differs, however. While the ratio of registered to bearer share prices is numerically higher for the December 1988 data than it was previously, it still is significantly less than one.

\section{The Increase In Neshle's Market Valne}

Table 3 shows the change in the market value of Nestle' shares from the end of July 1988 to the end of December 1988. As shown, the market value of Nestlé increased by almost 22 percent subsequent to its November policy change. Of course, this figure may over- or understate the change in value due to the policy change because other factors that affect stock prices may have changed.

To control for this, table 4 shows the percentage changes in the prices of bearer and nonvoting shares for the firms in our sample that do not issue registered shares. Since the Nestle announcement pertained only to the treatment of registered shareholders, it is unlikely that the announcement would affect the share prices of firms that issue no registered shares. Changes in the prices of these firms between July and December 1988 can be used to proxy the effect of changes in other factors on Swiss stock prices.

The discount is present in data extending back to

December 1975 
Table 3

The Change in the Market Value of Nestle: July 1988-December 1988

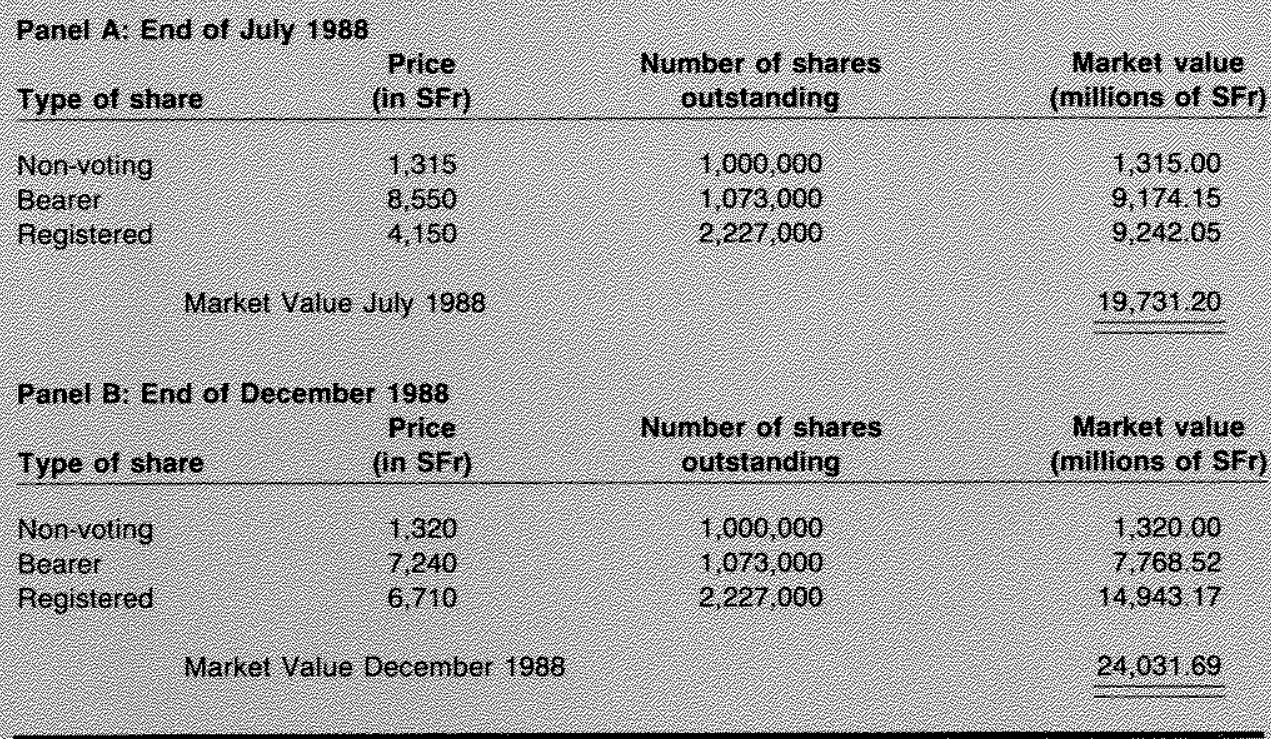

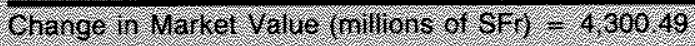

percentage Grange $=2$. $60 \%$

Table 4

\begin{tabular}{|c|c|c|}
\hline $\begin{array}{l}\text { A Proxy F } \\
\text { Other Fac } \\
\text { prices of } f \\
\text { shares. }\end{array}$ & $\begin{array}{l}\text { le Effect of } \\
\text { changes in } \\
\text { hat issue no }\end{array}$ & hare \\
\hline Type of Share & $\begin{array}{l}\text { Average percent } \\
\text { charge } \\
7188-12188\end{array}$ & 1)score \\
\hline Bearer & 7.970 & 188 \\
\hline Nort voling & 9.20 & 200 \\
\hline$N=9$ & & \\
\hline
\end{tabular}

The data in table 4 indicate that the share prices of these firms did not rise from July to December 1988. While the point estimates of the average percentage change are negative in both cases, they are not significantly different from zero. Thus, these data suggest that other general influences did not raise or lower Swiss stock prices from July to December 1988. Consequently, the 22 percent increase in the market value of Nestle can be taken as a "ball park" estimate of the rise in value associated with its change in registration policy.

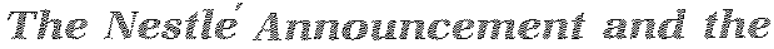 Shere probes of on}

The data in table 2 suggest that the ratio of registered to bearer share prices rose from July to December 1988 for the 36 firms that issue both types of shares. The data in table 5 show that the increase in this ratio resulted from a significant increase in the price of registered shares rather than from a decline in the price of bearer shares. This is important in evaluating whether the change in policy actually augments the shareholders' wealth. Any change that reduces the differences between the share types will cause their prices to converge even though stockholder wealth may not increase. For example, if the share prices converge because bearer and non-voting share prices generally decline while registered share prices remain unchanged, aggregate stockholder wealth will fall. If registered share prices increase while other 


\section{Table 5}

Percentage Changes in Share Prices: July-December 1988

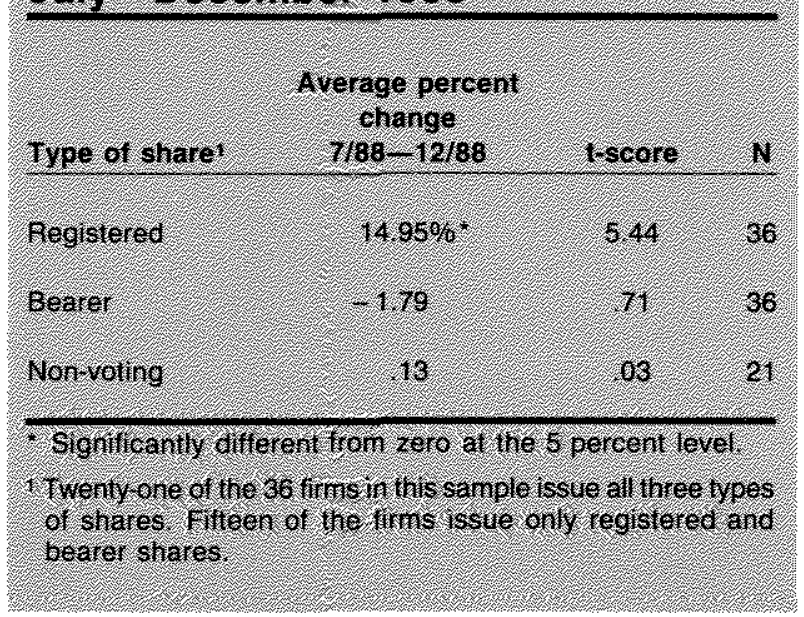

share prices are constant, however, aggregate wealth will increase.

The data in table 5 are consistent with the second case. Registered share prices increased by about 15 percent from July to December 1988 while changes in the prices of bearer and nonvoting shares are not significantly different from zero. Again, the table 4 data suggest that the increase in registered share prices is not due solely to other factors.

\section{CONOLUSION}

Recent experience with corporate takeovers has raised concerns that the capital of corporate shareholders is being held hostage by Wall Street power brokers. Accordingly, various reforms designed to reduce takeover activity have been proposed.

This paper examines an economic theory that treats the control of a firm as a valuable asset. The theory suggests that takeovers represent trades of this asset in a market for corporate control and that such market competition provides strong protection for the interests of shareholders.

Data on the Swiss stock market are analyzed to determine whether restricting the market for corporate control affects stockholder wealth. Until recently, ownership restrictions on Swiss registered shares had prevented foreign citizens from competing for control of many Swiss firms. These restrictions were relaxed in Nov- ember 1988. Data analyzed in this paper suggest that the registered share prices of firms rose by about 15 percent while the prices of bearer and non-voting shares were roughly constant following the relaxation. The data suggest that restricting competition in the market on corporate control can have serious adverse consequences on the wealth of shareholders. Since recent proposals to reform the takeover market in the United States intend to restrict this activity, they are likely to be counterproductive in protecting shareholder capital.

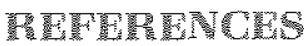

Alchian, Armen. Economic Forces at Work (Liberty Press, 1977).

Anders, George, and Steve Swartz. "Some Big Firms to Break Up Stock into New Securities," Wall Street Journal, December 5, 1988.

Brealey, R. A. An Introduction to Risk and Return from Common Stocks (The MIT Press, 1983).

Brealey, Fichard, and Stewart Myers. Principles of Corporate Finance (McGraw Hill, 1988).

Burrough, Brian. "Circus-Like Takeover Contest for RuR Nabisco Inc. Brings Forth 2 New Bids of More Than $\$ 108$ a Share," Wall Street Journal, December 1, 1988.

"CEOs React to RJR - and Ross Johnson." Wall Street Journal, December 2, 1988.

Dulforce, Williarn. "Swiss Life Wins Battle for La Suisse," Financial Times, August $9,1988$.

\section{"Nestle' to End Foreign Shares}

Discrimination," Financial Times, November 18, 1988. "Nestlé Breaks Market Mould," Financial Times, November 22, 1988.

Foreman, Craig. "Nestle' Copycat Fears Cloud Swiss Stocks," Wall Street Journal, November 21, 1988.

Grossman, Sanford J., and Oliver D. Hart. "One Share-One Vote and the Market for Corporate Control," Journal of Financial Economics (January/March 1988), pp. 175-202.

Hershey, Robert D. Jt. "Congress Is Moving Closer to Weighing Buyout Curbs," New York Times, December 5 , 1988.

Horner, Melchior R. "The Value of the Corporate Voting Right: Evidence from Switzerland," Journal of Banking and Finance (v. 12, 1988) pp. 69-83.

“Japan's Bias Against Domestic Mergers May Become Trade Issue, Tokyo Fears," Wall Street Journal, December 1, 1988.

Jarrell, Gregg A., and Annelte B. Poulson. "Dual Class Recapitalizations As Antitakeover Mechanisms: The Recent Evidence," Journal of Financial Economics (January/March 1988), pp. 129.52.

Jensen, Michael C, and Richard S. Ruback. "The Market for Corporate Control: The Scientific Evidence," Joumal of Financial Economics (April 1983), pp. 5-50.

Jensen, Michael $C$, and Jerold B. Warner. "The Distribution of Power Among Corporate Managers, Shareholders and Directors," Journal of Financial Economics (January/March 1988), pp. 3-24. 
Manne, Henry G. "Mergers and the Market for Corporate Controf," Journal of Political Economy (April 1965), pp. $110-20$.

Manne, Henry G., and Larry E. Ribstein. "The SEC v. the American Shareholder," National Review (November 25, 1988), pp. 26-29

Norris, Floyd. "A New Defense in Hostile Bids", New York Times, December 1, 1988.

Passell, Peter. "How to Defuse the Buyout Bomb:" New York Times, December $7,1988$.

Ricks, Thomas E. "SEC Staffers Link ' 87 Crash to House Panel," Wall Street Journal, May 4, 1989.

Ruback, Richard S. "Coercive Dual-Class Exchange Offers," Journal of Financial Economics (January/March 1988), pp. $153-73$
"Shareholders, Who Are They?" The Economist (January 28, 1989): p. 69

Stulz, Rene' M. "Managerial Control of Voling Pights: Financing Policies and the Market for Conporate Control," Jour" nal of Financial Economics (January/March 1988), pp. $25-54$.

Swiss Bank Corporation. Handbuch der Schweizer Aktien (1987)

Wicks, John. "Suchard Lets Foreigners Own Registered Shares," Financial Times, June 22, 1988.

"Unprecedented Battle of La Suisse Suitors""

Financial Times, August 2, 1988.

"Will Others Follow RJR as it Pioneers Megadeal Frontier?" Wall Street Journal, December 2, 1988

\section{Appendix}

\section{Firms Included in the Tests}

Types of Shares Issued

Firm

Elekrowatt

Fortuna

Gotthard Bank

Interdiscount

Pirelli

VP Bank Vaduz

Walter Rentsch

Zuercher

Ziegeleien

Zellweger

Allusuisse

B.S.I.

Bank Leu

Bobst

Brown Boveri

Buehrle

Ciba Geigy

Feldschloesschen

Georg Fischer

Haldengut

Jacobs Suchard

Konsumverein

Zurich

Moevenpick

Nestle

Registered Bearer Non-voting

Firm

Sandoz

Schindler

Swiss Bank

Corporation

Schweizer Rueck

Union Bank of

Switzerland

Zurich Insurance

Globus

Types of Shares Issued

Accu-Oerlikon

Charmilles

Credit Suisse

Crossair

Frisco Findus

Hermes

Hero

Huerlimann

Mikron

Usego

Eichhof

Holzstoff

Hypo Brugg

Sibra Holding

Swissair
Registered Bearer Non-voting

11

1

$\begin{array}{lll}1 & 1 & 1 \\ 1 & 1 & 1\end{array}$

1

$\begin{array}{lll}1 & 1 & 1 \\ 1 & 1 & 1 \\ 1 & 1 & 1\end{array}$

\begin{tabular}{ll}
1 & 1 \\
1 & 1 \\
1 & 1 \\
1 & 1 \\
1 & 1 \\
1 & 1 \\
1 & 1 \\
1 & 1 \\
1 & 1 \\
1 & 1 \\
1 & 1 \\
1 & 1 \\
1 & 1 \\
1 & 1 \\
1 & 1 \\
\hline
\end{tabular}

